\title{
POTENTIALS FOR TOURISM DEVELOPMENT BASED \\ ON PROTECTED NATURAL RESOURCES IN MORAVICA \\ ADMINISTRATIVE DISTRICT TERRITORY - OPINION OF THE \\ CITY OF ČAČAK RESIDENTS
}

\author{
Dušan Garabinović ${ }^{1}$, Marija Kostić2 ${ }^{2}$ Marija Lakićević ${ }^{3}$ \\ *Corresponding author E-mail: dusan.garabinovic.032@gmail.com
}

\begin{abstract}
A R T I C LE IN F O
Original Article

Received: 27 November 2020

Accepted: 08 December 2020

doi:10.5937/ekoPolj2004249G

UDC

338.486.027:338.483.11(497.11

Moravica)

Keywords:

nature-based tourism, natural potentials in tourism, protected natural resources, local population, moravica administrative district, the city of $\check{C} a \check{c} a k$

A B S T R A C T

The purpose of this paper is to indicate the potentials for tourism development based on the protected natural resources of the Republic of Serbia situated in the Moravica administrative district territory, the degree of their current utilization for the purposes of tourism and local population information on the above mentioned. Closed-ended survey was conducted (five-point scale) on the random sample of the residents in the urban part of the city of Čačak as the administrative centre of the Moravica administrative district. The results are: 1) low degree of information among the local population, 2) medium (good) potential for tourism development, and 3) very low level of its utilization for tourism purposes. The results are also considered according to the natural resources protection type. The contribution of this paper is in the indication of potentially successful elements in future tourism offer for the entities in the field of tourism and hospitality.
\end{abstract}

JEL: $Q 13$
(C) 2020 EA. All rights reserved.

\section{Introduction}

From its beginning, tourism has always been related to nature. Nature has determined, it still does, the potentials for tourism development in many regions, in combination with tourist offer social factors. According to its increasing importance, so called naturebased tourism, mainly based upon nature, takes an important place in the modern world

1 Dušan Garabinović, Higher business school of vocational studies "Prof. dr Radomir Bojković", Topličina 12, 37000 Kruševac, Phone: +381643929596, E-mail: dusan. garabinovic.032@gmail.com, ORCID ID (https://orcid.org/0000-0002-6247-3060)

2 Marija Kostić, Associate Professor, University of Kragujevac, Faculty of Hotel Management and Tourism in Vrnjačka Banja, Vojvođanska Street 5A, 36210 Vrnjačka Banja, Phone: +38162283124, E-mail: marija.kostic@kg.ac.rs, ORCID ID (https://orcid.org/0000-0001-8105-8033)

3 Marija Lakićević, Associate Professor, University of Kragujevac, Faculty of Hotel Management and Tourism in Vrnjačka Banja, Vojvođanska Street 5A, 36210 Vrnjačka Banja, Phone: +38162609204, E-mail: marija.lakicevic@kg.ac.rs, ORCID ID (https://orcid. org/0000-0003-2169-7575)

http://ea.bg.ac.rs 
(Nica et al., 2018; Popescu et al., 2017). Similar concepts are also ecotourism, green tourism, sustainable tourism, etc; what makes their essence is that they are based on natural resources of a specific climate and used for the purposes of tourism, but to the extent that allows natural resource preservation, potential improvement or completion.

If we consider nature-based tourism according to natural resource classification into geomorphological, hydrological, climate and biological, it is possible to single out and consider separately the types of tourism such as mountain tourism, speleotourism, river tourism, lake tourism, spa tourism, hunting tourism, fishing tourism, etc.

Relief shape is specific for a certain destination according to the actions of the numerous factors of its origin, as well as the factors influencing its changes. The significance of mountain tourism studies is also obvious in WoS and Scopus paper reviews conducted by Río-Rama et al. (2019). For example, Darmawan et al. (2018) contributed to naturebased tourism development through the feasibility study in Tembarak District (Central Java, Indonesia) by landscape image design creation.

Climate conditions can determine the conditions for tourism development, therefore some regions are convenient for winter tourism, others for summer tourism. The winter season can depend on climate changes, but primarily with the focus on the region where the activites are conducted, especially due to the possible extreme values (Tervo, 2008).

When we speak of flora and fauna, we should emphasize the possibilities for a large number of species, their varieties, autochthony, as well as conservation. It provides a foundation for hunting, fishing, observations, etc. Herbs should be singled out among plants since they could also provide the potential for sustainable tourism, such as the case of "Stara planina" nature park (Ratknić \& Milovanović, 2016). Naturally, people contribute to more complete usage of some natural potentials, so the benefits are used for the development of various types of tourism. For example wine tourism, which is extensively researched in the scientific and professional literature (Anđelić et al., 2019), organic production, as well as rural tourism, and closely observed agritourism as an addition to the existing types of contacts with clients and agricultural product distribution already discussed by Milanovic et al. (2019) and Milanović et al. (2020).

The role of protected natural resources and areas should be particularly emphasized within nature-based tourism. Accessibility orientation is particularly important for protected natural resources and tourism development (Tverijonaite et al., 2018). Accessibility can cause positive effects (higher numbers of tourists), as well as negative effects (degradation of nature).

Schirpke et al. (2018) indicate the role of protected areas for recreational activities, while Romagosa et al. (2015), Romagosa (2018) i Puhakka et al. (2017) emphasize the role of protected areas for human health. Wolf et al. (2017) provide a systematic review of papers on the topic of the role of protected areas in transformative travel. Protected resources and areas can be a great potential for tourist offer creation; therefore, Butzmann \& Job (2017) gave an example of Product-based Typology for Nature-based 
Tourism (PTNT) creation accordingly, referring to the protected areas, while Arnegger et al. (2010) highlighted their product-based typology.

Needless to say, there are also possible negative effects of tourism development in protected areas. Maldonado-Oré \& Custodio (2020) indicate the negative impact of tourists on protected natural areas, while Muboko et al. (2016) emphasize the examples of illegal hunting and wild animal poisoning. Visitor protection is also significant, along with tourist satisfaction, which is confirmed by Kubo \& Shoji (2016), Gstaettner, Kobryn et al. (2019), Gstaettner, Lee et al. (2019). According to the tendency for protected areas preservation, Weaver \& Lawton (2017) highlighted the significance of the third generation model, Snyman \& Bricker (2019) indicated that benefits should not be observed through financial aspect alone, but also through the benefit-sharing concept, while Slocum (2017) regarded simultaneous tendencies towards both sustainability and neo-liberalism. Yuan et al. (2015) established the subject area of sustainable tourism in the third place according to the number of documents, that is, papers (184) in ten leading journals in the field of tourism between 2008 and 2012. This subject area also includes four subtopics: Sustainability, ecotourism and environment (74); Climate change, carbon emission and travel scenario (60); Corporate social responsibility and green tourism (36); Tourism in protected areas (14).

Muñoz et al. (2019) indicate certain differences among local, domestic and foreign tourists in relation to the tourist values in protected areas, where we could highlight the significance of local tourists arising from the local population. This significance is also confirmed by Queiros \& Mearns (2019), implying local population attitudes on using protected areas for the purposes of tourism, based on benefits and losses comparison. Local population should be able to provide the best evaluation of the potentials because, in perspective, they have the best knowledge about the surrounding natural resources. Numerous authors delt with local population attitudes on tourism in nature - Chiu et al. (2016), Zhang \& Chan (2016), Lindberg \& Veisten (2012), etc.

Therefore, natural resources can contain great tourist potentials. This is the reason for many authors to assess the natural potentials for the development of tourism in certain areas. There are a lot of examples, Priskin (2001), Valjarević et al. (2017), Ghorbanzadeh et al. (2019), Hamdi et al. (2019), and others are only some of them.

It is necessary to underline that having potentials for the development of tourism based on natural resources is one thing, while using the available potentials for tourism purposes is something completely different. According to the above mentioned, the following part of this paper will point out the opinion of local population from the urban areas in the city of Čačak as the administrative centre of Moravica district on natural potentials and their utilization for the purposes of tourism, primarily when it comes to the protected natural resources.

The subject of this paper is protected natural resources of the Republic of Serbia situated in Moravica administrative district territory and their potential for the development of tourism. 
The aim of this paper is to establish the protected natural resources potentials of the Republic of Serbia situated in Moravica administrative district territory, their current utilization for the purposes of tourism, as well as the level of information among the local population (urban part of Čačak) on the above mentioned protected resources.

On the basis of the previously stated subject and aim of this paper, there are the following hypotheses:

H1 - The population in the urban territory of the city of Čačak shows a low level of information on the protected natural resources of the Republic of Serbia situated in the territory of Moravica administrative district;

H2 - The opinion of the population in the urban territory of the city of Čačak is that there is a good potential of the protected natural resources of the Republic of Serbia situated in Moravica administrative district for tourism development;

H3 - The opinion of the population in the urban territory of the city of Čačak is that there is a high level of dormancy related to the protected natural resources of the Republic of Serbia situated in Moravica administrative district for tourism purposes.

\section{The basic characteristics and the protected natural resources in Moravica administrative district}

Moravica administrative district is a part of the Republic of Serbia, with the area of around $3016 \mathrm{~km}^{2}$ (Moravica administrative distict, 2020), population 212603 (Statistical Office of the Republic of Serbia, 2014, p. 25); it consists of four local governments - the city of Čačak, the municipality of Lučani, the municipality of Ivanjica, the municipality of Gornji Milanovac.

The Institute for Nature Conservation of Serbia (ZZPS, 2019) analysis established (natural areas around protected cultural assets excluded) one nature park (Golija), one landscape of outstanding features (Ovčar-Kablar gorge), one area of exceptional natural beauty (Rajac), strict nature reserve (Veliki Šturac), followed by 3 monuments of nature (2 botanical - a group of eight turkey oak trees (Quercus cerris L.) Palibrčki cerovi, sorb tree (Sorbus domestica) in Prislonica village; 1 geological - "Mala Bezdan" cave), 18 monuments of nature (15 botanical - turkey oak tree - Donja Crnuća, common oak - Stražev, two common oak trees Djurdjevak, Radan's forest (in Serbian - Radanova gora), birch tree in Donja Kravarica, linden tree in Guča, cornel tree in Guberevci, Malt oak tree in Vlasteljice, cornel tree in Viča, field maple tree in Viča, linden tree in Pšanik, rubber fig tree - Čačak, Šumati Šumar - the Balkan beech tree, Gojković linden tree, the protected trees of Čačak; 3 geological - Rti cave, Ostrovica, Hadži-Prodan's cave).

\section{Materials and methods}

The research used surveys. The questions in the survey are closed-ended, they are based on the five-point scale assessment (1 - very low, 2 - low, 3 - medium, 4 - high, 5 - very high). There are three groups, and they refer to: (1) Information on protected 
natural resources of the Republic of Serbia situated in Moravica administrative district territory, (2) Protected natural resources of the Republic of Serbia situated in Moravica administrative district territory potential for tourism development, (3) Protected natural resources of the Republic of Serbia situated in Moravica administrative district existing utilization for tourism purposes.

115 residents of the urban part of the city of Cačak territory took part in the survey, that is, from the central city zone. The city of Čačak is selected as the administrative centre of the Moravica administrative district. The survey was conducted offline, anonymously, by random sampling. We can see the structure of the samples in the following table (Table 1.).

Table 1. The structure of the respondents by gender, age and education level

\begin{tabular}{|c|c|c|c|c|c|c|c|c|c|}
\hline & \multicolumn{2}{|c|}{ Gender } & \multicolumn{4}{|c|}{ Years of age } & \multicolumn{3}{|c|}{ Level of education } \\
\hline & Male & Female & $\leq 25$ & $26-40$ & $41-60$ & $\geq 61$ & Elementary & Secondary & Higher \\
\hline No. & 41 & 74 & 6 & 37 & 59 & 13 & 1 & 79 & 35 \\
\hline$\%$ & 35.65 & 64.35 & 5.22 & 32.17 & 51.30 & 11.30 & 0.87 & 68.70 & 30.43 \\
\hline
\end{tabular}

Source: Authors'research

As we can see in Table 1, the total structure of the respondents is dominated by female respondents, 41-60 years of age, with secondary education. Respondents evaluated 25 protected natural resources (listed in the previous chapter of this paper), by protection type.

\section{Results and discussion}

The following table (Table 2.) provides an overview on local population in urban parts of Čačak information on protected natural resources of the Republic of Serbia situated in the territory of Moravica administrative district.

Table 2. Information on protected natural resources of the Republic of Serbia situated in the territory of Moravica administrative district territory

\begin{tabular}{|l|r|r|r|r|r|r|c|}
\hline \multirow{2}{*}{\multicolumn{1}{|c|}{ Natural resource }} & \multicolumn{7}{|c|}{ Information evaluation } \\
\cline { 2 - 9 } & Very low & Low & Medium & High & $\begin{array}{c}\text { Very } \\
\text { high }\end{array}$ & AG & Desc \\
\hline Ovčar-Kablar gorge & 0.87 & 1.74 & 9.57 & 29.57 & 58.26 & 4.43 & High \\
\hline Rubber fig tree - Čačak & 11.30 & 4.35 & 13.04 & 14.78 & 56.52 & 4.43 & High \\
\hline Golija & 9.57 & 22.61 & 36.52 & 15.65 & 15.65 & 4.01 & Medium \\
\hline Rajac & 33.91 & 22.61 & 22.61 & 6.96 & 13.91 & 3.05 & Low \\
\hline Caves in Rti & 66.09 & 6.09 & 11.30 & 6.96 & 9.57 & 2.24 & Low \\
\hline Linden tree in Guča & 72.17 & 8.70 & 4.35 & 1.74 & 13.04 & 1.88 & Low \\
\hline Hadži-Prodan's cave & 70.43 & 13.04 & 5.22 & 2.61 & 8.70 & 1.75 & Low \\
\hline Ostrovica & 89.57 & 0.00 & 2.61 & 0.87 & 6.96 & 1.66 & Very low \\
\hline $\begin{array}{l}\text { Sorb tree (Sorbus } \\
\text { domestica) in Prislonica } \\
\text { village }\end{array}$ & 86.09 & 5.22 & 4.35 & 0.00 & 4.35 & 1.36 & Very low \\
\hline
\end{tabular}




\begin{tabular}{|c|c|c|c|c|c|c|c|}
\hline \multirow[b]{2}{*}{ Natural resource } & \multicolumn{7}{|c|}{ Information evaluation } \\
\hline & Very low & Low & Medium & High & $\begin{array}{l}\text { Very } \\
\text { high }\end{array}$ & AG & Desc \\
\hline $\begin{array}{l}\text { Turkey oak tree - Donja } \\
\text { Crnuća }\end{array}$ & 86.09 & 3.48 & 6.09 & 4.35 & 0.00 & 1.31 & Very low \\
\hline $\begin{array}{l}\text { Birch tree in Donja } \\
\text { Kravarica }\end{array}$ & 87.83 & 5.22 & 4.35 & 1.74 & 0.87 & 1.29 & Very low \\
\hline Common oak - Stražev & 89.57 & 4.35 & 6.09 & 0.00 & 0.00 & 1.23 & Very low \\
\hline $\begin{array}{l}\text { The protected trees of } \\
\text { Čačak }\end{array}$ & 90.43 & 2.61 & 3.48 & 0.87 & 2.61 & 1.23 & Very low \\
\hline "Mala Bezdan" cave & 92.17 & 3.48 & 2.61 & 0.87 & 0.87 & 1.17 & Very low \\
\hline Cornel tree in Viča & 93.04 & 5.22 & 0.00 & 0.00 & 1.74 & 1.15 & Very low \\
\hline $\begin{array}{l}\text { A group of eight turkey oak } \\
\text { trees (Quercus cerris L.) - } \\
\text { Palibrčki cerovi }\end{array}$ & 94.78 & 0.00 & 4.35 & 0.87 & 0.00 & 1.12 & Very low \\
\hline Gojković linden tree & 94.78 & 1.74 & 1.74 & 1.74 & 0.00 & 1.11 & Very low \\
\hline $\begin{array}{l}\text { Radan's forest (in Serbian - } \\
\text { Radanova gora) }\end{array}$ & 94.78 & 1.74 & 3.48 & 0.00 & 0.00 & 1.1 & Very low \\
\hline Field maple tree in Viča & 94.78 & 4.35 & 0.00 & 0.00 & 0.87 & 1.09 & Very low \\
\hline Cornel tree in Guberevci & 97.39 & 0.87 & 0.00 & 0.87 & 0.87 & 1.08 & Very low \\
\hline $\begin{array}{l}\text { Two common oak trees } \\
\text { Djurdjevak }\end{array}$ & 97.39 & 0.87 & 0.87 & 0.87 & 0.00 & 1.07 & Very low \\
\hline Veliki Šturac & 97.39 & 1.74 & 0.87 & 0.00 & 0.00 & 1.05 & Very low \\
\hline Malt oak tree in Vlasteljice & 99.13 & 0.00 & 0.00 & 0.87 & 0.00 & 1.03 & Very low \\
\hline Linden tree in Pšanik & 99.13 & 0.00 & 0.00 & 0.00 & 0.87 & 1.03 & Very low \\
\hline $\begin{array}{l}\text { Šumati šumar - the Balkan } \\
\text { beech tree }\end{array}$ & 99.13 & 0.00 & 0.87 & 0.00 & 0.00 & 1.03 & Very low \\
\hline $\begin{array}{l}\text { Notes: The percentage ( } \%- \\
\text { number of the respondents }(1 \\
\text { high } 4.5 \leq \mathrm{AG} \leq 5 \text {, high } 3.5 \leq \mathrm{A}\end{array}$ & ry low, lo & , mediu & high, very & igh) is & culate & it of the & $\begin{array}{l}\text { total } \\
\text { AG): very } \\
<1.5 \text {; The }\end{array}$ \\
\hline
\end{tabular}

\section{Source: Authors' research}

It is evident that information level on none of the resources is evaluated as very high $(0.00 \%)$, while high information level is present on two of the resources $(8.00 \%)$, both from the city of Čačak territory (Ovčar-Kablar gorge and Rubber fig tree), while medium information level is present when we speak about one of the natural resources (Golija). Low information level is present in four of the natural resources (16.00\%). Very low, that is, insufficient level of information is the most represented - in case of 18 natural resources $(72.00 \%)$.

The following table (Table 3.) provides the evaluation on information level about protected natural resources of the Republic of Serbia situated situated in Moravica administrative district according to the protection type. 
Table 3. Evaluation on information about protected natural resources of the Republic of Serbia situated in Moravica administrative district (according to the protection type)

\begin{tabular}{|c|c|c|c|c|c|c|c|c|c|c|c|c|c|}
\hline \multirow{3}{*}{\multicolumn{2}{|c|}{$\begin{array}{c}\text { Protection } \\
\text { type }\end{array}$}} & \multirow{3}{*}{$\begin{array}{l}\text { No. } \\
\text { NR }\end{array}$} & \multicolumn{10}{|c|}{ Information evaluation } & \multirow[b]{3}{*}{ Avg. } \\
\hline & & & \multicolumn{2}{|c|}{ Very high } & \multicolumn{2}{|c|}{ High } & \multicolumn{2}{|c|}{ Medium } & \multicolumn{2}{|c|}{ Low } & \multicolumn{2}{|c|}{ Very low } & \\
\hline & & & No. & $\%$ & No. & $\%$ & No. & $\%$ & No. & $\%$ & No. & $\%$ & \\
\hline \multicolumn{2}{|c|}{ Nature park } & 1 & 0 & 0.00 & 0 & 0.00 & 1 & 100.00 & 0 & 0.00 & 0 & 0.00 & 3.05 \\
\hline \multicolumn{2}{|c|}{ Landscapes } & 2 & 0 & 0.00 & 1 & 50.00 & 0 & 0.00 & 1 & 50.00 & 0 & 0.00 & 3.35 \\
\hline \multicolumn{2}{|c|}{ Reserve } & 1 & 0 & 0.00 & 0 & 0.00 & 0 & 0.00 & 0 & 0.00 & 1 & 100.00 & 1.03 \\
\hline \multirow{3}{*}{ 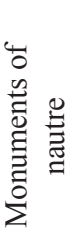 } & $M N-U$ & 21 & 0 & 0.00 & 1 & 4.76 & 0 & 0.00 & 3 & 14.29 & 17 & 80.95 & 1.37 \\
\hline & $M N-B$ & 17 & 0 & 0.00 & 1 & 5.88 & 0 & 0.00 & 1 & 5.88 & 15 & 88.24 & 1.33 \\
\hline & $M N-G$ & 4 & 0 & 0.00 & 0 & 0.00 & 0 & 0.00 & 2 & 50.00 & 2 & 50.00 & 1.51 \\
\hline \multicolumn{2}{|c|}{ TOTAL } & 25 & 0 & 0.00 & 2 & 8.00 & 1 & 4.00 & 4 & 16.00 & 18 & 72.00 & 1.58 \\
\hline
\end{tabular}

Notes: No. NR - the number of protected natural resources; \% - number of protected natural resources percentage; Avg. - the average - the sum of protected natural resources average grade belonging to the certain protection type divided by the number of protected natural resources in that protection type (No. NR); MN-T - monuments of nature (total); MN-B - monuments of nature (botanical); MN-G monuments of nature (geological); TOTAL - refers to the total number of protected natural resources analyzed, where percentage and average are calculated out of the total number (25).

\section{Source: Authors'research}

Average information grade per natural resource is 1.58 . When we speak of natural resources protection type, information level can be ordered as follows: landscapes (medium), nature park (medium), natural monuments/monuments of nature (very low, with the exception of geological ones - low), reserve (very low).

The following table (Table 4.) provides an overview of protected natural resource of the Republic of Serbia situated in Moravica administrative district territory potentials for tourism development.

Table 4. Protected natural resources potentials of the Republic of Serbia situated in Moravica administrative district territory for tourism development

\begin{tabular}{|l|c|r|r|r|r|r|r|c|}
\hline \multirow{2}{*}{ Natural resource } & \multirow{2}{*}{$\begin{array}{c}\text { No. of } \\
\text { answers }\end{array}$} & $\begin{array}{l}\text { Very } \\
\text { low }\end{array}$ & \multicolumn{1}{|c|}{ Low } & Medium & \multicolumn{1}{|c|}{ High } & Very high & AG & Desc \\
\hline $\begin{array}{l}\text { Malt oak tree in } \\
\text { Vlasteljice }\end{array}$ & 1 & 0.00 & 0.00 & 0.00 & 0.00 & 100.00 & 5.00 & Very high \\
\hline $\begin{array}{l}\text { Linden tree in } \\
\text { Pšanik }\end{array}$ & 1 & 0.00 & 0.00 & 0.00 & 0.00 & 100.00 & 5.00 & Very high \\
\hline $\begin{array}{l}\text { Ovčar-Kablar } \\
\text { gorge }\end{array}$ & 114 & 0.00 & 0.00 & 3.51 & 8.77 & 87.72 & 4.84 & Very high \\
\hline Golija & 104 & 0.00 & 0.00 & 7.69 & 29.81 & 62.50 & 4.55 & Very high \\
\hline Rajac & 76 & 0.00 & 0.00 & 19.74 & 35.53 & 44.74 & 4.25 & High \\
\hline Caves in Rti & 39 & 0.00 & 5.13 & 20.51 & 38.46 & 35.90 & 4.05 & High \\
\hline
\end{tabular}




\begin{tabular}{|c|c|c|c|c|c|c|c|c|}
\hline \multirow[b]{2}{*}{ Natural resource } & \multirow{2}{*}{$\begin{array}{c}\text { No. of } \\
\text { answers }\end{array}$} & \multirow[b]{2}{*}{$\begin{array}{l}\text { Very } \\
\text { low }\end{array}$} & \multicolumn{6}{|c|}{ Potentials evaluation } \\
\hline & & & Low & Medium & High & Very high & AG & Desc \\
\hline $\begin{array}{l}\text { Šumati šumar - } \\
\text { the Balkan beech } \\
\text { tree }\end{array}$ & 1 & 0.00 & 0.00 & 0.00 & 100.00 & 0.00 & 4.00 & High \\
\hline $\begin{array}{l}\text { Hadži-Prodan's } \\
\text { cave }\end{array}$ & 34 & 0.00 & 17.65 & 32.35 & 14.71 & 35.29 & 3.68 & High \\
\hline $\begin{array}{l}\text { "Mala Bezdan" } \\
\text { cave }\end{array}$ & 9 & 0.00 & 22.22 & 22.22 & 22.22 & 33.33 & 3.67 & High \\
\hline $\begin{array}{l}\text { Two common oak } \\
\text { trees Djurdjevak }\end{array}$ & 3 & 0.00 & 33.33 & 0.00 & 33.33 & 33.33 & 3.67 & High \\
\hline Ostrovica & 12 & 0.00 & 16.67 & 33.33 & 33.33 & 16.67 & 3.50 & High \\
\hline $\begin{array}{l}\text { Rubber fig tree - } \\
\text { Čačak }\end{array}$ & 102 & 7.84 & 20.59 & 34.31 & 20.59 & 16.67 & 3.18 & Medium \\
\hline $\begin{array}{l}\text { A group of eight } \\
\text { turkey oak trees } \\
\text { (Quercus cerris } \\
\text { L.) - Palibrčki } \\
\text { cerovi }\end{array}$ & 6 & 16.67 & 16.67 & 33.33 & 16.67 & 16.67 & 3.00 & Medium \\
\hline $\begin{array}{l}\text { Linden tree in } \\
\text { Guča }\end{array}$ & 32 & 6.25 & 25.00 & 46.88 & 9.38 & 12.50 & 2.97 & Medium \\
\hline $\begin{array}{l}\text { Sorb tree (Sorbus } \\
\text { domestica) in } \\
\text { Prislonica village }\end{array}$ & 16 & 18.75 & 31.25 & 18.75 & 0.00 & 31.25 & 2.94 & Medium \\
\hline $\begin{array}{l}\text { Gojković linden } \\
\text { tree }\end{array}$ & 6 & 16.67 & 16.67 & 33.33 & 33.33 & 0.00 & 2.83 & Medium \\
\hline $\begin{array}{l}\text { The protected } \\
\text { trees of Čačak }\end{array}$ & 11 & 9.09 & 45.45 & 27.27 & 0.00 & 18.18 & 2.73 & Medium \\
\hline $\begin{array}{l}\text { Birch tree in } \\
\text { Donja Kravarica }\end{array}$ & 14 & 14.29 & 28.57 & 42.86 & 0.00 & 14.29 & 2.71 & Medium \\
\hline $\begin{array}{l}\text { Radan's forest } \\
\text { (in Serbian - } \\
\text { Radanova gora) }\end{array}$ & 6 & 16.67 & 33.33 & 33.33 & 0.00 & 16.67 & 2.67 & Medium \\
\hline $\begin{array}{l}\text { Turkey oak tree - } \\
\text { Donja Crnuća }\end{array}$ & 16 & 12.50 & 25.00 & 56.25 & 6.25 & 0.00 & 2.56 & Medium \\
\hline Veliki Šturac & 3 & 33.33 & 33.33 & 0.00 & 33.33 & 0.00 & 2.33 & Low \\
\hline $\begin{array}{l}\text { Common oak - } \\
\text { Stražev }\end{array}$ & 12 & 11.11 & 100.00 & 0.00 & 11.11 & 11.11 & 2.33 & Low \\
\hline $\begin{array}{l}\text { Cornel tree in } \\
\text { Guberevci }\end{array}$ & 3 & 33.33 & 33.33 & 0.00 & 33.33 & 0.00 & 2.33 & Low \\
\hline $\begin{array}{l}\text { Cornel tree in } \\
\text { Viča }\end{array}$ & 8 & 25.00 & 50.00 & 12.50 & 0.00 & 12.50 & 2.25 & Low \\
\hline $\begin{array}{l}\text { Field maple tree } \\
\text { in Viča }\end{array}$ & 6 & 33.33 & 50.00 & 0.00 & 0.00 & 16.67 & 2.17 & Low \\
\hline
\end{tabular}




\begin{tabular}{|c|c|c|c|c|c|c|c|c|}
\hline \multirow[b]{2}{*}{ Natural resource } & \multirow{2}{*}{$\begin{array}{c}\text { No. of } \\
\text { answers }\end{array}$} & & \multicolumn{6}{|c|}{ Potentials evaluation } \\
\hline & & $\begin{array}{l}\text { Very } \\
\text { low }\end{array}$ & Low & Medium & High & Very high & AG & Desc \\
\hline \multicolumn{9}{|c|}{$\begin{array}{l}\text { Notes: No. of answers - the number of respondents with the information level on protected natural } \\
\text { resource } \geq 2 \text {. and therefore they could evaluate the potential of the natural resource for tourism } \\
\text { development. The percentage (\% - very low, low, medium, high, very high) is calculated out of the } \\
\text { number of the answers (No. of answers); } A G \text { - Average grade; Desc - Description - average grade } \\
\text { (AG): very high } 4.5 \leq A G \leq 5 \text {, high } 3.5 \leq A G<4.5 \text {, medium } 2.5 \leq A G<3.5 \text {, low } 1.5 \leq A G<2.5 \text {, very low } \\
1 \leq A G<1.5 \text {; The order starting from the highest to the lowest average grade (AG). }\end{array}$} \\
\hline
\end{tabular}

\section{Source: Authors'research}

The table above shows that there are only four protected natural resources with a very high potential for tourism development (16.00\%); we can make it certain for OvčarKablar gorge and Golija according to the number of respondents, unlike in case of Malt oak tree in Vlasteljice and Linden tree in Pšanik evaluated by only one person each. High potential is present in 7 protected natural resources $(28.00 \%)$, while medium is present in $9(36.00 \%)$, and low in $5(20.00 \%)$. It is evident that in none of the cases the potential can be evaluated as very low.

The following table (Table 5.) provides the evaluation of protected natural resources of the Republic of Serbia situated in Moravica administrative district territory for tourism development according to the protection type.

Table 5. The evaluation of protected natural resources of the Republic of Serbia situated in Moravica administrative district territory for tourism development

(according to the protection type)

\begin{tabular}{|c|c|c|c|c|c|c|c|c|c|c|c|c|c|}
\hline \multirow{3}{*}{\multicolumn{2}{|c|}{$\begin{array}{c}\text { Protection } \\
\text { type }\end{array}$}} & \multirow{3}{*}{$\begin{array}{l}\text { No. } \\
\text { NR }\end{array}$} & \multicolumn{10}{|c|}{ Potentials evaluation } & \multirow{3}{*}{ Avg. } \\
\hline & & & \multicolumn{2}{|c|}{ Very high } & \multicolumn{2}{|c|}{ High } & \multicolumn{2}{|c|}{ Medium } & \multicolumn{2}{|c|}{ Low } & \multicolumn{2}{|c|}{ Very low } & \\
\hline & & & No. & $\%$ & No. & $\%$ & No. & $\%$ & No. & $\%$ & No. & $\%$ & \\
\hline \multicolumn{2}{|c|}{ Nature park } & 1 & 1 & 100.00 & 0 & 0.00 & 0 & 0.00 & 0 & 0.00 & 0 & 0.00 & 4.55 \\
\hline \multicolumn{2}{|c|}{ Landscapes } & 2 & 0 & 0.00 & 2 & 100.00 & 0 & 0.00 & 0 & 0.00 & 0 & 0.00 & 4.37 \\
\hline \multicolumn{2}{|c|}{ Reserve } & 1 & 0 & 0.00 & 0 & 0.00 & 0 & 0.00 & 1 & 100.00 & 0 & 0.00 & 2.33 \\
\hline \multirow{3}{*}{ 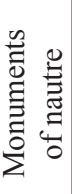 } & $M N-U$ & 21 & 2 & 9.52 & 6 & 28.57 & 9 & 42.86 & 4 & 19.05 & 0 & 0.00 & 3.20 \\
\hline & $M N-B$ & 17 & 2 & 11.76 & 2 & 11.76 & 9 & 52.94 & 4 & 23.53 & 0 & 0.00 & 3.08 \\
\hline & $M N-G$ & 4 & 0 & 0.00 & 4 & 100.00 & 0 & 0.00 & 0 & 0.00 & 0 & 0.00 & 3.73 \\
\hline \multicolumn{2}{|c|}{ TOTAL } & 25 & 4 & 16.00 & 7 & 28.00 & 9 & 36.00 & 5 & 20.00 & 0 & 0.00 & 3.33 \\
\hline
\end{tabular}

Notes: No. NR - the number of protected natural resources; \% - number of protected natural resources percentage; Avg. - the average - the sum of protected natural resources average grade belonging to the certain protection type divided by the number of protected natural resources in that protection type (No. NR); MN-T - monuments of nature (total); MN-B - monuments of nature (botanical); $\mathrm{MN}-\mathrm{G}-$ monuments of nature (geological); TOTAL - refers to the total number of protected natural resources analyzed, where percentage and average are calculated out of the total number (25).

Source: Authors'research 
Average potential grade per natural resource is 3.33 . When we speak of the natural resources protection type, the potential for tourism development can be ordered as follows: nature park (very high), landscapes (high), monuments of nature/natural monuments (medium, except geological ones - high), reserves (low).

The following table (Table 6.) provides an overview of the existing utilization for tourism development when we speak of protected natural resources of the Republic of Serbia situated in Moravica administrative district territory.

Table 6. Protected natural resources of the Republic of Serbia situated in Moravica administrative district territory existing utilization for tourism development

\begin{tabular}{|c|c|c|c|c|c|c|c|c|}
\hline \multirow[b]{2}{*}{ Natural resource } & \multirow{2}{*}{$\begin{array}{c}\text { No. of } \\
\text { answers }\end{array}$} & \multicolumn{7}{|c|}{ Utilization evaluation } \\
\hline & & Very low & Low & Medium & High & $\begin{array}{l}\text { Very } \\
\text { high } \\
\end{array}$ & AG & Desc \\
\hline Ovčar-Kablar gorge & 114 & 14.91 & 33.33 & 33.33 & 15.79 & 2.63 & 2.58 & Medium \\
\hline Golija & 104 & 16.35 & 39.42 & 37.50 & 6.73 & 0.00 & 2.35 & Low \\
\hline Rajac & 76 & 22.37 & 53.95 & 21.05 & 1.32 & 1.32 & 2.05 & Low \\
\hline $\begin{array}{l}\text { Linden tree in } \\
\text { Pšanik }\end{array}$ & 1 & 0.00 & 100.00 & 0.00 & 0.00 & 0.00 & 2.00 & Low \\
\hline Linden tree in Guča & 32 & 53.13 & 15.63 & 25.00 & 6.25 & 0.00 & 1.84 & Low \\
\hline Ostrovica & 12 & 41.67 & 41.67 & 8.33 & 8.33 & 0.00 & 1.83 & Low \\
\hline $\begin{array}{l}\text { The protected trees } \\
\text { of Čačak }\end{array}$ & 11 & 63.64 & 18.18 & 9.09 & 0.00 & 9.09 & 1.73 & Low \\
\hline Caves in Rti & 39 & 48.72 & 38.46 & 10.26 & 2.56 & 0.00 & 1.67 & Low \\
\hline $\begin{array}{l}\text { Rubber fig tree - } \\
\text { Čačak }\end{array}$ & 102 & 58.82 & 27.45 & 6.86 & 2.94 & 3.92 & 1.66 & Low \\
\hline $\begin{array}{l}\text { Sorb tree (Sorbus } \\
\text { domestica) in } \\
\text { Prislonica village }\end{array}$ & 16 & 81.25 & 0.00 & 6.25 & 6.25 & 6.25 & 1.56 & Low \\
\hline $\begin{array}{l}\text { A group of eight } \\
\text { turkey oak trees } \\
\text { (Quercus cerris L.) } \\
\text { - Palibrčki cerovi }\end{array}$ & 6 & 66.67 & 16.67 & 16.67 & 0.00 & 0.00 & 1.50 & Low \\
\hline $\begin{array}{l}\text { Hadži-Prodan's } \\
\text { cave }\end{array}$ & 34 & 64.71 & 29.41 & 2.94 & 2.94 & 0.00 & 1.44 & Very low \\
\hline $\begin{array}{l}\text { Birch tree in Donja } \\
\text { Kravarica }\end{array}$ & 14 & 78.57 & 7.14 & 14.29 & 0.00 & 0.00 & 1.36 & Very low \\
\hline $\begin{array}{l}\text { "Mala Bezdan" } \\
\text { cave }\end{array}$ & 9 & 77.78 & 11.11 & 11.11 & 0.00 & 0.00 & 1.33 & Very low \\
\hline $\begin{array}{l}\text { Gojković linden } \\
\text { tree }\end{array}$ & 6 & 66.67 & 33.33 & 0.00 & 0.00 & 0.00 & 1.33 & Very low \\
\hline Cornel tree in Viča & 8 & 75.00 & 25.00 & 0.00 & 0.00 & 0.00 & 1.25 & Very low \\
\hline $\begin{array}{l}\text { Turkey oak tree - } \\
\text { Donja Crnuća }\end{array}$ & 16 & 93.75 & 6.25 & 0.00 & 0.00 & 0.00 & 1.06 & Very low \\
\hline Veliki Šturac & 3 & 100.00 & 0.00 & 0.00 & 0.00 & 0.00 & 1.00 & Very low \\
\hline
\end{tabular}




\begin{tabular}{|c|c|c|c|c|c|c|c|c|}
\hline \multirow[b]{2}{*}{ Natural resource } & \multirow{2}{*}{$\begin{array}{c}\text { No. of } \\
\text { answers }\end{array}$} & \multicolumn{7}{|c|}{ Utilization evaluation } \\
\hline & & Very low & Low & Medium & High & $\begin{array}{l}\text { Very } \\
\text { high } \\
\end{array}$ & AG & Desc \\
\hline $\begin{array}{l}\text { Common oak - } \\
\text { Stražev }\end{array}$ & 12 & 100.00 & 0.00 & 0.00 & 0.00 & 0.00 & 1.00 & Very low \\
\hline $\begin{array}{l}\text { Two common oak } \\
\text { trees Djurdjevak }\end{array}$ & 3 & 100.00 & 0.00 & 0.00 & 0.00 & 0.00 & 1.00 & Very low \\
\hline $\begin{array}{l}\text { Radan's forest (in } \\
\text { Serbian - Radanova } \\
\text { gora) }\end{array}$ & 6 & 100.00 & 0.00 & 0.00 & 0.00 & 0.00 & 1.00 & Very low \\
\hline $\begin{array}{l}\text { Cornel tree in } \\
\text { Guberevci }\end{array}$ & 3 & 100.00 & 0.00 & 0.00 & 0.00 & 0.00 & 1.00 & Very low \\
\hline $\begin{array}{l}\text { Malt oak tree in } \\
\text { Vlasteljice }\end{array}$ & 1 & 100.00 & 0.00 & 0.00 & 0.00 & 0.00 & 1.00 & Very low \\
\hline $\begin{array}{l}\text { Field maple tree in } \\
\text { Viča }\end{array}$ & 6 & 100.00 & 0.00 & 0.00 & 0.00 & 0.00 & 1.00 & Very low \\
\hline $\begin{array}{l}\text { Šumati šumar - the } \\
\text { Balkan beech tree }\end{array}$ & 1 & 100.00 & 0.00 & 0.00 & 0.00 & 0.00 & 1.00 & Very low \\
\hline \multicolumn{9}{|c|}{$\begin{array}{l}\text { Notes: No. of answers - the number of respondents with the information level on protected natural } \\
\text { resource } \geq 2 \text {. and therefore they could evaluate the utilization of the natural resource for tourism } \\
\text { development; The percentage ( } \% \text { - very low, low, medium, high, very high) is calculated out of the } \\
\text { number of the answers (No. of answers); } A G \text { - Average grade; Desc - Description - average grade } \\
\text { (AG): very high } 4.5 \leq A G \leq 5 \text {, high } 3.5 \leq A G<4.5 \text {, medium } 2.5 \leq A G<3.5 \text {, low } 1.5 \leq A G<2.5 \text {, very low } \\
1 \leq A G<1.5 \text {; The order starting from the highest to the lowest average grade (AG). }\end{array}$} \\
\hline
\end{tabular}

\section{Source: Authors'research}

As it is evident from the table above (Table 6.), Ovčar-Kablar gorge has the best utilization (medium utilization). Most of the protected natural resources $(14.56 \%)$ are represented by very low utilization, while a significant percentage has low utilization $(10 ; 40.00 \%)$, and a small number has medium utilization $(1 ; 4.00 \%)$.

The following table (Table 7.) provides the evaluation of protected natural resources utilization for tourism development according to the protection type. 
Table 7. The evaluation of the Republic of Serbia protected natural resources situated in Moravica administrative district utilization for tourism development (according to the protection type)

\begin{tabular}{|c|c|c|c|c|c|c|c|c|c|c|c|c|c|}
\hline \multirow{3}{*}{\multicolumn{2}{|c|}{$\begin{array}{c}\text { Protection } \\
\text { type }\end{array}$}} & \multirow{3}{*}{$\begin{array}{l}\text { No. } \\
\text { NR }\end{array}$} & \multicolumn{10}{|c|}{ Utilization evaluation } & \multirow{3}{*}{ Avg. } \\
\hline & & & \multicolumn{2}{|c|}{ Very high } & \multicolumn{2}{|c|}{ High } & \multicolumn{2}{|c|}{ Medium } & \multicolumn{2}{|c|}{ Low } & \multicolumn{2}{|c|}{ Very low } & \\
\hline & & & No. & $\%$ & No. & $\%$ & No. & $\%$ & No. & $\%$ & No. & $\%$ & \\
\hline \multicolumn{2}{|c|}{ Nature park } & 1 & 0 & 0.00 & 0 & 0.00 & 0 & 0.00 & 1 & 100.00 & 0 & 0.00 & 2.35 \\
\hline \multicolumn{2}{|c|}{ Landmarks } & 2 & 0 & 0.00 & 0 & 0.00 & 1 & 50.00 & 1 & 50.00 & 0 & 0.00 & 2.32 \\
\hline \multicolumn{2}{|c|}{ Reserve } & 1 & 0 & 0.00 & 0 & 0.00 & 0 & 0.00 & 0 & 0.00 & 1 & 100.00 & 1.00 \\
\hline \multirow{3}{*}{ 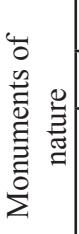 } & $M N-U$ & 21 & 0 & 0.00 & 0 & 0.00 & 0 & 0.00 & 8 & 38.10 & 13 & 61.90 & 1.36 \\
\hline & $M N-B$ & 17 & 0 & 0.00 & 0 & 0.00 & 0 & 0.00 & 6 & 35.29 & 11 & 64.71 & 1.31 \\
\hline & $M N-G$ & 4 & 0 & 0.00 & 0 & 0.00 & 0 & 0.00 & 2 & 50.00 & 2 & 50.00 & 1.57 \\
\hline \multicolumn{2}{|c|}{ TOTAL } & 25 & 0 & 0.00 & 0 & 0.00 & 1 & 4.00 & 10 & 40.00 & 14 & 56.00 & 1.46 \\
\hline \multicolumn{14}{|c|}{$\begin{array}{l}\text { Notes: No. P.R. - the number of protected natural resources; } \% \text { - number of protected natural resources } \\
\text { percentage; Avg. - Average - the sum of protected natural resources average grade belonging to the } \\
\text { certain protection type divided by the number of protected natural resources in that protection type } \\
\text { (No. NR); MN-T - monuments of nature (total); MN-B - monuments of nature (botanical); MN-G - } \\
\text { monuments of nature (geological); TOTAL - refers to the total number of protected natural resources } \\
\text { analyzed, where percentage and average are calculated out of the total number (25). }\end{array}$} \\
\hline
\end{tabular}

Source: Authors'research

Average utilization grade per natural resource is 1.46 . When it comes to natural resources protection type, utilization for tourism purposes can be ordered as follows: landscapes (low), monuments of nature (very low, except in case of geological resources - low), reserve (very low).

\section{Conclusion}

As it is evident from this research conducted in the urban territories of the city of Čačak, there is a low level of information among local population about the protected natural resources of the Republic of Serbia situated in Moravica administrative district territory. There is a high level of information only about Ovčar-Kablar gorge and Rubber fig tree, while the level is medium only about Golija. With the average level of information per protected natural resource of 1.58 (low information), we can make a clear conclusion that H1 is confirmed. There is a very high potential for tourism development in 4 protected natural resources, high -7 , medium -9 , while the rest of the resources have a low or very low potential. The average grade on potential per protected natural resource is medium (3.33). Therefore, the aforementioned confirms $\mathbf{H} 2$ hypothesis. Protected natural resources utilization for tourism development is only evaluated as medium in case of Ovčar-Kablar gorge, while it is very low or low in case of other protected natural resources. The average utilization for tourism development per natural resource is very low (1.46). Therefore, the aforementioned confirms $\mathbf{H 3}$ hypothesis. 
Very low information level among local population in urban areas of the city of Čačak, potential for tourism development at the medium level, as well as very low utilization of protected natural resources for tourism development in Moravica administrative district territory indicate the key issues in nature-based tourism development, especially tourism related to protected natural resources.

The limitations of this research refer to the survey intended for the population of the urban areas of the city of Cačak, not the population in the other areas of Moravica administrative district, or the absence of other subjects in tourism and hospitality sector. Previously highlighted limitations represent the foundation for further research with the focus on the complete Moravica district territory, as well as other interest groups in the field of tourism and hospitality.

\section{Conflict of interests}

The authors declare no conflict of interest.

\section{References}

1. Anđelić, S., Garabinović, D., \& Šormaz, G. (2019). A review of wine and wine tourism presence in the scientific papers in journals in the field of tourism. Economics of Agriculture, 66(4), 1055-1090. https://doi.org/10.5937/ekoPolj1904055A

2. Arnegger, J., Woltering, M., \& Job, H. (2010). Toward a product-based typology for nature-based tourism: a conceptual framework. Journal of sustainable tourism, 18(7), 915-928. https://doi.org/10.1080/09669582.2010.485680

3. Butzmann, E., \& Job, H. (2017). Developing a typology of sustainable protected area tourism products. Journal of Sustainable Tourism, 25(12), 1736-1755. https:// doi.org/10.1080/09669582.2016.1206110

4. Chiu, H. Y., Chan, C. S., \& Marafa, L. M. (2016). Local perception and preferences in nature tourism in Hong Kong. Tourism Management Perspectives, 20, 87-97. https://doi.org/10.1016/j.tmp.2016.07.007

5. Darmawan, E., Arfa, M., \& Purbawati, D. L. (2018). The development of nature based-tourism in Tembarak District, Temanggung Regency. Asia Pacific Journal of Tourism Research, 23(9), 924-934. https://doi.org/10.1080/10941665.2018.1510423

6. Ghorbanzadeh, O., Pourmoradian, S., Blaschke, T., \& Feizizadeh, B. (2019). Mapping potential nature-based tourism areas by applying GIS-decision making systems in East Azerbaijan Province, Iran. Journal of Ecotourism, 18(3), 261-283. https://doi.org/10.1080/14724049.2019.1597876

7. Gstaettner, A. M., Kobryn, H. T., Rodger, K., Phillips, M., \& Lee, D. (2019). Monitoring visitor injury in protected areas-analysis of incident reporting in two Western Australian parks. Journal of Outdoor Recreation and Tourism, 25, 143157. https://doi.org/10.1016/j.jort.2018.04.002 
8. Gstaettner, A. M., Lee, D., Weiler, B., \& Rodger, K. (2019). Visitor safety in recreational protected areas: Exploring responsibility-sharing from a management perspective. Tourism Management, 75, 370-380. https://doi.org/10.1016/j. tourman.2019.06.007

9. Hamdi, A. E., Maryati, M., \& Hamdin, M. S. (2019). The Potential of Nature Tourism at Muar and Tangkak Districts, Johor, Malaysia. In IOP Conference Series: Earth and Environmental Science (Vol. 269, No. 1, p. 012008). IOP Publishing. doi:10.1088/1755-1315/269/1/012008; Retrieved from: https://iopscience.iop.org/ article/10.1088/1755-1315/269/1/012008/pdf (14.09.2020., 09:10).

10. Institute for nature conservation of Serbia, http://www.zzps.rs, $\left(20^{\text {th }}\right.$ December 2019).

11. Kubo, T., \& Shoji, Y. (2016). Demand for bear viewing hikes: Implications for balancing visitor satisfaction with safety in protected areas. Journal of outdoor recreation and tourism, 16, 44-49. https://doi.org/10.1016/j.jort.2016.09.004

12. Lindberg, K., \& Veisten, K. (2012). Local and non-local preferences for nature tourism facility development. Tourism Management Perspectives, 4, 215-222. https://doi.org/10.1016/j.tmp.2012.08.004

13. Maldonado-Oré, E. M., \& Custodio, M. (2020). Visitor environmental impact on protected natural areas: An evaluation of the Huaytapallana Regional Conservation Area in Peru. Journal of Outdoor Recreation and Tourism, 100298. https://doi. org/10.1016/j.jort.2020.100298

14. Milanovic, J., Garabinovic, D. \& Nikitovic, Z. (2019). The influence of product turnover on the market as a part of the distribution channel of agricultural products to increase competitiveness. In Nikitovic, Z., Vujicic, S. \& Piljan, I. (Eds) Thematic proceedings, Eighth International Scientific Conference Employment, Education and Entrepreneurship (pp. 122-128), 17-19 October 2019, Belgrade, Serbia.

15. Milanović, J., Nikitović, Z., \& Garabinović, D. (2020). The impact of customer contact as part of the agricultural products distribution channel on the increase of the competitiveness of agricultural holdings. Economics of Agriculture, 67(2), 359375. https://doi.org/10.5937/ekoPolj2002359M

16. Moravica administrative district, https://moravicki.okrug.gov.rs (14 ${ }^{\text {th }}$ September 2020)

17. Muboko, N., Gandiwa, E., Muposhi, V., \& Tarakini, T. (2016). Illegal hunting and protected areas: Tourist perceptions on wild animal poisoning in Hwange National Park, Zimbabwe. Tourism Management, 52, 170-172. https://doi.org/10.1016/j. tourman.2015.06.023

18. Muñoz, L., Hausner, V., Brown, G., Runge, C., \& Fauchald, P. (2019). Identifying spatial overlap in the values of locals, domestic-and international tourists to protected areas. Tourism Management, 71, 259-271. https://doi.org/10.1016/j. tourman.2018.07.015 
19. Nica, E., Sima, V., Gheorghe, I., \& Drugau-Constantin, A. (2018). Analysis of Regional Disparities in Romania from an Entrepreneurial Perspective. Sustainability, 10(10), 3450. https://doi.org/10.3390/su10103450

20. Popescu, G. H., Sima, V., Nica, E., \& Gheorghe, I. G. (2017). Measuring sustainable competitiveness in contemporary economies-Insights from European economy. Sustainability, 9(7), 1230. https://doi.org/10.3390/su9071230

21. Priskin, J. (2001). Assessment of natural resources for nature-based tourism: the case of the Central Coast Region of Western Australia. Tourism management, 22(6), 637-648. https://doi.org/10.1016/S0261-5177(01)00039-5

22. Puhakka, R., Pitkänen, K., \& Siikamäki, P. (2017). The health and well-being impacts of protected areas in Finland. Journal of Sustainable Tourism, 25(12), 1830-1847. https://doi.org/10.1080/09669582.2016.1243696

23. Queiros, D., \& Mearns, K. (2019). Khanyayo village and Mkhambathi Nature Reserve, South Africa: a pragmatic qualitative investigation into attitudes towards a protected area. Journal of Sustainable Tourism, 27(6), 750-772. https://doi.org/1 0.1080/09669582.2018.1436177

24. Ratknić, T., \& Milovanović, J. (2016). Medicinal herbs as part of the development of sustainable tourism in nature park "Stara planina". Economics of Agriculture, 63(3), 847-860. https://doi.org/10.5937/ekoPolj1603847R

25. Río-Rama, M., Maldonado-Erazo, C., Durán-Sánchez, A., \& Álvarez-García, J. (2019). Mountain tourism research. A review. European Journal of Tourism Research, 22, 130-150.

26. Romagosa, F. (2018). Physical health in green spaces: Visitors' perceptions and activities in protected areas around Barcelona. Journal of Outdoor Recreation and Tourism, 23, 26-32. https://doi.org/10.1016/j.jort.2018.07.002

27. Romagosa, F., Eagles, P. F. J., \& Lemieux, C. J. (2015). From the inside out to the outside in: Exploring the role of parks and protected areas as providers of human health and well-being. Journal of Outdoor Recreation and Tourism, 10, 70-77. https://doi.org/10.1016/j.jort.2015.06.009

28. Schirpke, U., Scolozzi, R., Da Re, R., Masiero, M., Pellegrino, D., \& Marino, D. (2018). Recreational ecosystem services in protected areas: A survey of visitors to Natura 2000 sites in Italy. Journal of outdoor recreation and tourism, 21, 39-50. https://doi.org/10.1016/j.jort.2018.01.003

29. Slocum, S. L. (2017). Operationalising both sustainability and neo-liberalism in protected areas: implications from the USA's National Park Service's evolving experiences and challenges. Journal of Sustainable Tourism, 25(12), 1848-1864. https://doi.org/10.1080/09669582.2016.1260574

30. Snyman, S., \& Bricker, K. S. (2019). Living on the edge: Benefit-sharing from protected area tourism. Journal of Sustainable Tourism, 27(6), 705-719. https://doi. org/10.1080/09669582.2019.1615496 
31. Statistical Office of the Republic of Serbia (2014). Comparative overview of the number of population in 1948, 1953, 1961, 1971, 1981, 1991, 2002 and 2011. Data by settlements. 2011 Census of Population, Households and Dwellings in the Republic of Serbia. Population. Retrieved from https:/pod2.stat.gov.rs/ ObjavljenePublikacije/Popis2011/Knjiga20.pdf (14 ${ }^{\text {th }}$ September 2020)

32. Tervo, K. (2008). The operational and regional vulnerability of winter tourism to climate variability and change: The case of the Finnish nature-based tourism entrepreneurs. Scandinavian Journal of Hospitality and Tourism, 8(4), 317-332. https://doi.org/10.1080/15022250802553696

33. Tverijonaite, E., Ólafsdóttir, R., \& Thorsteinsson, T. (2018). Accessibility of protected areas and visitor behaviour: A case study from Iceland. Journal of outdoor recreation and tourism, 24, 1-10. https://doi.org/10.1016/j.jort.2018.09.001

34. Valjarević, A., Vukoičić, D., \& Valjarević, D. (2017). Evaluation of the tourist potential and natural attractivity of the Lukovska Spa. Tourism management perspectives, 22, 7-16. https://doi.org/10.1016/j.tmp.2016.12.004

35. Weaver, D. B., \& Lawton, L. J. (2017). A new visitation paradigm for protected areas. Tourism Management, 60, 140-146. https://doi.org/10.1016/j. tourman.2016.11.018

36. Wolf, I. D., Ainsworth, G. B., \& Crowley, J. (2017). Transformative travel as a sustainable market niche for protected areas: a new development, marketing and conservation model. Journal of Sustainable Tourism, 25(11), 1650-1673. https:// doi.org/10.1080/09669582.2017.1302454

37. Yuan, Y., Gretzel, U., \& Tseng, Y. H. (2015). Revealing the nature of contemporary tourism research: Extracting common subject areas through bibliographic coupling. International Journal of Tourism Research, 17(5), 417-431.

38. Zhang, S., \& Chan, C. S. (2016). Nature-based tourism development in Hong Kong: Importance-Performance perceptions of local residents and tourists. Tourism Management Perspectives, 20, 38-46. https://doi.org/10.1016/j.tmp.2016.07.002 